\title{
Alternatives for Research Valorization: A Case Study for the ROMIMAG Project
}

\author{
E. Ciocoiu, M. Dan, A. Mihăilă, and E. Crişan
}

\begin{abstract}
The valorization of research results is a major challenge for both researchers and organizations, especially in the context of projects that do not create new products, technologies or other tangible results. This can lead to low rates of results usage and even low return on investment for these projects. The intention of this paper is to propose alternatives for research results valorization of the ROMIMAG project. The project main goal is to analyze the Romanian imaginary, so implicitly it is a project that will deliver intangible research results. These proposals are made considering multiple elements: research results nature, its activities peculiarities, its stakeholders' categories, traditional valorization strategies presented in literature, the Romanian scientific research context, and the current valorization strategy of the project. This case study concludes that the best alternatives for diversifying ROMIMAG valorization strategy are to perform promotion activities that target the general public and to enlarge the current classical promotion strategy by including alternate modern promotion strategies.
\end{abstract}

Index Terms-Knowledge transfer, valorization, ROMIMAG, technology transfer.

\section{INTRODUCTION}

Romania is behind others EU Member States in terms of research, development and innovation capacity. In 2012, R\&D spending equaled $0.19 \%$ of GDP, seven times lower than the EU average. This indicator has continued its decline in 2013 , reaching $0.12 \%$ of GDP (despite the existing tax incentives for eligible R\&D costs). Research and development under-funding influences the research system in structural terms, resulting in brain drain and a decline in the quality of human skills. Cooperation between public and private sectors in the field of research is also low. The low level of investment in R\&D contrasts the relatively high level of total investment in the country [1]. There is a clear and persistent division across the EU concerning R\&D. First, there is the East-West division, with a generally lower quality of public systems R\&D in Eastern European countries, compared to other Western States. Secondly, there is also a North-South division, though less pronounced. To a large extent, these divisions are the result of more public investment low in $\mathrm{R} \& \mathrm{D}$ in countries that are lagging behind [2].

In this context, the goal of this article is to search on the processes performed within Romanian universities, in order to improve R\&D outcomes. More precisely, our goal is to

Manuscript received November 30, 2018; revised June 13, 2019.

The authors are with Babeş-Bolyai University, Romania (e-mail: eugenia.ciocoiu@econ.ubbcluj.ro, madalina.dan@econ.ubbcluj.ro, alin.mihaila@econ.ubbcluj.ro, emil.crisan@con.ubbcluj.ro). develop a new valorization strategy for a Romanian research project, based on a detailed literature review of the recommended valorization strategies, but also on a detailed analysis of project's current valorization strategy. A conclusion that can be made regarding project's current valorization is that it is mainly publishing oriented and does not encourage technology or knowledge transfer activities. The new strategy we propose enlarges the current classical promotion strategy by including alternate promotion strategies, as searching for partners from business and nonprofit organizations willing to engage in this research project. The paper further reviews research valorization alternatives (second chapter). In the third chapter the ROMIMAG project is presented, its valorization strategy is analyzed and recommendations are made. The final part concludes.

\section{LITERATURE REVIEW}

Scientific research can be described as risky and uncertain, this being one of the reasons why university projects stakeholders should consider different strategies to search for successful products and services. These is similar to projects implemented in the private environment. Valorization encompasses all activities that contribute to ensuring that the results of scientific knowledge add value beyond the scientific domain. It includes making academic results available or more easily accessible, in order to increase the chances of other-academia-making use of it, as well as co-production of knowledge with non-academic groups [3]. Another form of valorization of the final and partial results is the transformation of knowledge and skills in patents, which protect new technical solutions, not necessarily final products, but which guarantees the intellectual property, the industrial property of these results. In the literature, there are various ways of capitalizing and marketing, starting from the most common ones, such as patenting an idea or invention, to very complex and elaborate methods such as the creation of spin-offs and start-ups. Such methods have led to an "academic revolution" due to the fact that universities have become much more entrepreneurial.

Valorization of research results is a very important element for universities. This activity increases the involvement of universities in the regional ecosystem. Supporting an innovation-based economy means evolving, adapting, reinventing, and using existing ideas and information in existing and/or new products and services. This extended valorization strategy encourages the creation of an innovation ecosystem through public-private partnerships and public-public partnerships. Market mechanisms stimulate 
innovative entrepreneurship and the involvement of enterprises in research, development and innovation. This industry valorization strategy is presented by literature as technology transfer. Technology transfer (TT) from university to industry has become strategically important in many respects: it represents a source of funding for university research, a source of innovation for businesses, and is a source of economic development for policy makers. Industrial policy relies increasingly on TT as a tool for the development of knowledge intensive economies and increased competitiveness [3]. As universities become more entrepreneurial and look at technology transfer in non-traditional areas, alternative technology transfer concepts, that are more precise and realistic than the traditional linear model, and are generalizable to the nuances of the universe to which they are applied, are needed [4]. The main purpose of a technology transfer program is for the university to help its researchers in disseminating research results for the public good. The degree of success depends not only on the nature of the interface between the university and the business community, but also on the receptivity in the surrounding community, as well as on the culture, organization and incentives within the universities themselves [5].

\begin{tabular}{l} 
TABLE I: KEY DIMENSIONS OF TECHNOLOGY AND KNOWLEDGE TRANSFER \\
\begin{tabular}{|l|l|l|}
\hline Knowledge Transfer & $\begin{array}{l}\text { Technology } \\
\text { Transfer }\end{array}$ \\
\hline Disciplines & $\begin{array}{l}\text { It can be used by a large } \\
\text { number of different } \\
\text { disciplines }\end{array}$ & $\begin{array}{l}\text { It is used in applied } \\
\text { sciences and } \\
\text { engineering. }\end{array}$ \\
\hline Partners & $\begin{array}{l}\text { Commercial and } \\
\text { non-commercial } \\
\text { companies }\end{array}$ & $\begin{array}{l}\text { Commercial } \\
\text { companies, investors, } \\
\text { corporations }\end{array}$ \\
\hline $\begin{array}{l}\text { Nature of } \\
\text { Knowledge }\end{array}$ & Explicit / Tacit & Explicit \\
\hline $\begin{array}{l}\text { Source of } \\
\text { knowledge }\end{array}$ & $\begin{array}{l}\text { Experts (coming from a } \\
\text { wider range of disciplines } \\
\text { than technology transfer) }\end{array}$ & $\begin{array}{l}\text { Experts Reports } \\
\text { Intellectual capital } \\
\text { Technologies } \\
\text { Laboratory } \\
\text { Research work }\end{array}$ \\
\hline $\begin{array}{l}\text { Transfer } \\
\text { mechanisms }\end{array}$ & $\begin{array}{l}\text { Research Contracts } \\
\text { Consulting } \\
\text { Collaborative research } \\
\text { Knowledge transfer } \\
\text { partnership }\end{array}$ & $\begin{array}{l}\text { Patenting / Patenting } \\
\text { Research Contracts } \\
\text { Collaborative } \\
\text { research }\end{array}$ \\
\hline Investment funds for \\
research \\
Incubators Spin-offs / \\
Star-ups (Academic)
\end{tabular} \\
\hline
\end{tabular}

Another strategy is knowledge transfer. Knowledge transfer between universities and industry takes place through a variety of mechanisms [6], ranging from recruitment of university graduates to personnel exchanges, joint research, contract research, consulting, patents and publications, licensing, spin-off companies, industry funded laboratories and other facilities, and also informal contacts such as meetings and conferences. Universities can capitalize on their new knowledge and technology through different methods, depending on the specificity of the research area, the university's objectives in relation to their transfer, the strategy adopted the long-term results they want.
A comparison between the two major strategies is presented in Table I. Both strategies are traditionally implemented through University Technology Transfer Offices (TTOs). These structures need a wide range of abilities to facilitate commercial exploitation of research outputs; however, we know relatively little about how these important abilities are developed and refined over time.

In literature, there are also several types of collaborations between academia and non-profit organizations. Roper has identified five types of collaborations taking into account the purpose of the collaboration, the initiator and the level of participation of each collaborator [7]. The first two types are expert-consultant and expert-trainer, collaborations in which the academic partner is regarded as an expert whose role is to identify deficiencies and improve the work of the non-profit organization. The third type of collaboration is a common learning model, that is, partners are co-productions of the acquired knowledge. Such collaboration is focused on long-term and collaborative sustainability rather than on short-term benefits. The partners share the same interest in research and the same vision about the partnership. The last two types of collaboration are the best practice model and the theoretical development model. The best practice model assumes that the partner from the academic environment identifies and documents the best practices of the nonprofit organization with which it collaborates to be used by other similar organizations. The theoretical development model focuses more on building the theory using empirical evidence collected from the nonprofit organization.

The first way Petrusson recommends to promote the use of knowledge is to make them available to the general public, being the most popular method [8]. Public access to knowledge can be done through academic publishing, academic education and popular scientific activities. Academic publishing includes the publication of scientific articles in various international journals, the publication of books, textbooks and other reports and presentation of ideas at conferences to be included in conference papers. Academic education means that the results achieved through the publication of courses and seminars, manuals and other educational materials. As far as popular scientific activities are concerned, they include open access lectures, participation in scientific fairs, and dissemination of scientific knowledge by radio or TV.

The second method of disseminating knowledge acquired in the academic environment is to allow access to knowledge only for certain categories of stakeholders and users who are directly interested in this information. The objective of this method is to ensure the implementation of the acquired knowledge. This dissemination of knowledge can be achieved through research activities, educational activities and knowledge transfer [9] classified the knowledge into four categories: Semiotics, Ownership \&reach, Generalizability, Propositionality.

Semiotics is tacit knowledge and explicit knowledge.

Ownership \&reach are Individual knowledge and collective knowledge. Generalizability is specific knowledge and general knowledge. Propositionality is declarative knowledge and procedural knowledge. The research activities are carried out by concluding research contracts or 
collaborative research. These two methods seek to use the knowledge gained in the academic environment to solve specific problems of the collaborators. Educational activities imply that certain stakeholder categories may require researchers to transfer research results using educational tools Knowledge transfer can be achieved through consultancy services provided by researchers to business partners to facilitate the practical use of knowledge.

The third method of disseminating knowledge in Petrusson's opinion is to promote that knowledge should be utilized in innovation projects. The last method proposed by the same author is to make knowledge available in open contractual networks.

More details concerning these promoting strategies are presented in Table II.

\section{The ROMIMAG CASE STUdY}

A case study is appropriate to begin with exploring a little-known concept, such as valorizing socio-cultural projects results. This qualitative method is really adapted to understand a complex organizational phenomenon.

TABLE II: TOOLS AND MECHANISMS USED TO PROMOTE THE USE OF KNOWLEDGE $^{1}$

\begin{tabular}{|c|c|c|c|}
\hline $\begin{array}{l}\text { Knowledge } \\
\text { is available } \\
\text { to the } \\
\text { public }\end{array}$ & $\begin{array}{l}\text { Knowledge is } \\
\text { available and } \\
\text { applicable to } \\
\text { certain } \\
\text { stakeholders }\end{array}$ & $\begin{array}{l}\text { Knowledge is } \\
\text { available as } \\
\text { products and } \\
\text { will be used in } \\
\text { innovation }\end{array}$ & $\begin{array}{l}\text { Knowledge is } \\
\text { available in } \\
\text { contract } \\
\text { structures / } \\
\text { networks } \\
\text { (Knowledge } \\
\text { Platforms) }\end{array}$ \\
\hline $\begin{array}{l}\text { Academic } \\
\text { Education: } \\
\text { Courses and } \\
\text { seminars } \\
\text { Manuals } \\
\text { Other } \\
\text { educational } \\
\text { materials }\end{array}$ & $\begin{array}{l}\text { Educational } \\
\text { activities: } \\
\text { Education } \\
\text { contracts } \\
\text { Internships for } \\
\text { students } \\
\text { Manuals and } \\
\text { other books }\end{array}$ & $\begin{array}{l}\text { Innovations } \\
\text { integrated in } \\
\text { education: } \\
\text { Innovation } \\
\text { project for } \\
\text { students }\end{array}$ & $\begin{array}{l}\text { "Commons" } \\
\text { Database } \\
\text { Software } \\
\text { Platforms }\end{array}$ \\
\hline $\begin{array}{l}\text { Popular } \\
\text { science } \\
\text { activities: } \\
\text { Social } \\
\text { media } \\
\text { (Radio, TV) } \\
\text { Websites }\end{array}$ & $\begin{array}{l}\text { Knowledge } \\
\text { transfer: } \\
\text { Providing trusted } \\
\text { positions } \\
\text { Partnership } \\
\text { programs and } \\
\text { collaborations } \\
\text { Licenses } \\
\text { /Development } \\
\text { projects } \\
\text { Consulting } \\
\text { services } \\
\text { Social Dialogue } \\
\text { Researchers are } \\
\text { hired by external } \\
\text { actors }\end{array}$ & $\begin{array}{l}\text { Innovations are } \\
\text { developed outside } \\
\text { the academic } \\
\text { environment: } \\
\text { In an } \\
\text { incubator-type } \\
\text { project associated } \\
\text { with the } \\
\text { university } \\
\text { By the } \\
\text { Technology } \\
\text { Transfer Office } \\
\text { Star-ups } \\
\text { /Spin-offs } \\
\text { Private } \\
\text { companies }\end{array}$ & $\begin{array}{l}\text { Open } \\
\text { innovation } \\
\text { platforms } \\
\text { Databases for } \\
\text { innovation } \\
\text { purposes } \\
\text { Software } \\
\text { developed } \\
\text { openly } \\
\text { Innovation } \\
\text { Platforms }\end{array}$ \\
\hline
\end{tabular}

\section{A. Analysis of the Current Situation}

The Encyclopedia of Imaginations in Romania Historical heritage and cultural-linguistic identities (ROMIMAG) aims to produce a "knowledge base" and a five-volume Encyclopedia to offer a synoptic perspective on cultural heritage and spiritual identities in Romania. The aim of the project is to improve the relations between the communities

\footnotetext{
${ }^{1}$ https://ec.europa.eu/jrc/sites/jrcsh/files/20160930-macroregional-innov ation-petrusson_en.pdf
}

living in Romania and the prevention of latent tensions and social violence. The main form of valorization on research results within the ROMIMAG project is their communication.

The ROMIMAG project aims to cover the following 5 areas of study: Heritage and linguistic imaginary; Literary imaginary; Historical imagery; Religious imagery; Artistic imagery. The estimated results of the project are as follows: o Five-volume encyclopedia, 40 scientific articles, 28 documentary shorts, 2 national conferences, 1 international congress, 2 press conferences, 1 site, 1 patent, and 1 new product conservation). From the perspective of correlating a minimum financial return with the mission and objectives assumed by the university in which it operates), the SWOT analysis provides the relevant information.

Following the description of the ROMIMAG project, it can be noticed that the project results will be largely in the form of knowledge and only a product in the form of a conservation technology. Because the details of the technology that will be created are not sufficient, the alternatives for capitalizing on the results of this article will focus on the knowledge gained in this project. Considering the results of the ROMIMAG project mentioned above, it can be concluded that promoting the use of knowledge is made by making available to the public all the knowledge gained in the project. From the description of the project, it can be seen that all project partners, both national and international, are universities or individuals affiliated to research centers.

\section{B. Alternative Strategies for Project Valorization}

Strategy 1: Searching for partners from business and nonprofit organizations willing to engage in this research project

Taking into account the two conclusions regarding the above-mentioned ROMIMAG project, namely that the resulting knowledge will be available to the general public without restriction and that the project partners come from the academic environment, the alternatives for capitalizing on the results proposed in this article are: looking for partners from business or nonprofit organizations to engage in collaborative research. This model is better suited for the transfer of knowledge than for inventions or technologies.

\begin{tabular}{|c|c|}
\hline STRENGTHS & WEAKNESSES \\
\hline $\begin{array}{l}\text { 1. Innovative project. } \\
\text { 2. Multiple Forms Results: The } \\
\text { research team multidisciplinary } \\
\text { 3. Five distinct research areas }\end{array}$ & $\begin{array}{l}\text { 1. The reward system is based } \\
\text { on scientific publications. } \\
2 . \text { Research results is not an } \\
\text { alternative taken into account } \\
\text { by researchers. } \\
\text { 3. Decrease in public funding } \\
\text { 4. Uncertainty of long-term } \\
\text { prospects. }\end{array}$ \\
\hline OPPORTUNITIES & THREATS \\
\hline $\begin{array}{l}\text { 1. TT and valorization at regional } \\
\text { and national levels. } \\
\text { 2. ROMIMAG to become a Brand } \\
\text { and Geographical Indication. } \\
\text { 3. The partial results in part are } \\
\text { promoted by TT. } \\
\text { Partnership with other universities. }\end{array}$ & $\begin{array}{l}\text { 1. Work only focuses on } \\
\text { research, not on the final. } \\
\text { 2. Risky to recovering the } \\
\text { investment. } \\
\text { 3. The results of the project will } \\
\text { not necessarily commercial } \\
\text { successes. }\end{array}$ \\
\hline
\end{tabular}

This collaboration is beneficial to both parties involved, so the outcome of the collaboration will be a win-win situation due to the fact that non-profit organizations provide access to 
their experience and empirical evidence, while the academic partner brings theoretical background and methodological expertise. In the case of the ROMIMAG project, collaboration with one or more non-profit organizations would be structured according to the common learning model, the two collaborators would be co-producers of the knowledge they obtained.

Strategy 2: Enlarge the current classical promotion strategy by including alternate modern promotion strategies

The academic environment is working to make the knowledge available to the public. They are transferred to the public without imposing any intellectual property restriction; by creating digital deposits. Professionals of high school education will attend courses and short-term seminars organized by academic specialists to be informed about the results of the research. Each partner of the project will promote the ROMIMAG project on their web page, materials published online, including web pages, newsletters, social networking (Facebook, LinkedIn).

The official project page will have videos, PDFs, and photos through which the ROMIMAG project is presented as an example. Changing and adapting the web page - a more user-friendly interface would make it easier to read.

There will be information about ROMIMAG, including on Wikipedia and on YouTube will be 5-minute videos (1 minute for each project) in which will be presented in very simple language what the project means and why it is so important.

\section{CONCLUSIONS}

There are a lot of models and tools in the literature used to harness or promote or disseminate the results of a project. In the case of ROMIMAG, with the exception of a product, namely a conservation technology, all results are new knowledge; so the project results are from the knowledge transfer category.

The results of a project may be available to the public without any restriction, or may be applicable and available only to a stakeholder category, or may be in the form of a product which may subsequently be converted into an invention or available only within a structure or contract networks.

In the case of the ROMIMAG project, it was found that the results would be for the public, so the proposal is to use a dissemination method only for a certain category of stakeholders. The proposed method is collaborative research, in partnership with a nonprofit organization In the ROMIMAG project, researchers did not aim to market the results of the research. Publication of research results in specialized journals is one of the main ways in which research results are shared.

Within the ROMIMAG project, there are elements of intellectual property through copyright and industrial property stemming from the patent. The impact that research results will have on the chosen target group can also be increased by choosing a brand as part of the valorization strategy. The main objective of the project is to make the most of the research results in order to achieve a cultural and social impact at different levels: local, regional, national and international.

\section{ACKNOWLEDGMENT}

This work was supported by a grant of the Romanian Ministry of Research and Innovation, CCCDI - UEFISCDI, project number PN-III-P1-1.2-PCCDI-2017-0326/49 PCCDI, within PNCDI III.

\section{REFERENCES}

[1] European Commission, "RIO country report Romania 2014," 2015.

[2] European Comission, "European semester thematic factsheet Research and innovation," vol. 11, 2018.

[3] B. Bozeman, "Technology transfer and public policy: A review of research and theory," Res. Policy, vol. 29, no. 4-5, pp. 627-655, 2000.

[4] J. Bercovitz and M. Feldman, "Entpreprenerial universities and technology transfer: A conceptual framework for understanding knowledge-based economic development," J. Technol. Transf., vol. 31, no. 1, pp. 175-188, Jan. 2006.

[5] A. N. Link B. Bozeman, "An empirical analysis of the propensity of academics to engage in informal university technology transfer," 2006.

[6] P. D'Estea and M. Perkmann, "Why do academics engage with industry? The entrepreneurial university and individual motivations".

[7] Roper, "Innovation and export performance: Evidence from UK and German manufacturing Plants," 2002.

[8] U. Petrusson, Research and Utilization, Göteborg: Tre böcker, 2016.

[9] F. Wijnhoven, "Manufacturing knowledge work: The European perspective," Methods and Tools for Effective Knowledge Life-Cycle-Management, Berlin, Heidelberg: Springer Berlin Heidelberg, 2008, pp. 23-44.

Copyright $($ C 2019 by the authors. This is an open access article distributed under the Creative Commons Attribution License which permits unrestricted use, distribution, and reproduction in any medium, provided the original work is properly cited (CC BY 4.0).

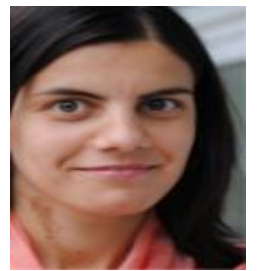

E. Ciocoiu was born in Bucharest on August 28, 1979). She was $\mathrm{PhD}$ student at the Faculty of Economics and Business Administration, "Babeş-Bolyai" University, Cluj-Napoca. She got the master in Human Resources Faculty of Management, "University of Economic Studies Bucharest", (2006); the bachelor in administrative sciences (2004), "University of Economic Studies Bucharest", 2006. She is a research assistant in the ROMIMAG project - "Babeş-Bolyai" University (UBB) Cluj-Napoca. 